\title{
PENGARUH PERPUTARAN PIUTANG DAN PERPUTARAN KAS TERHADAP LIKUIDITAS PADA PT. ULTRAJAYA MILK INDUSTRY DAN TRADING COMPANY, Tbk.
}

\author{
Dewi Lestari, \\ N. Rusnaeni \\ Universitas Pamulang \\ Nrusnaeni17@gmail.com
}

\begin{abstract}
The purpose of this research is to know the rotation of receivable at similar company of industry (Milk Management), to know the cash turnover in similar company of industry (Milk Management), and to know how big influence of receivable turnover and cash turn over to liquidity in similar industry Milk Management). The method of research conducted by the author in preparing the thesis is descriptive quantitative, which is doing research that describes the financial condition of the company expressed in the form of numbers. The data used are secondary data in the form of financial statements of Ultrajaya Milk Industry \& Trading Company, Tbk. for a period of 10 years from 2005-2014, obtained through ICAMEL (Indonesian Capital Market Electronic Library). The analysis method used is multiple linear regression analysis, classical assumption test, correlation coefficient, determination coefficient and hypothesis test. Based on the results of data analysis, multiple linear regression analysis results obtained regression equation $Y=-44.3620 .587 X 10.108 X 2$. Simultaneously variable receivable turnover and cash turnover affect the liquidity it can be seen from the value of $f$ arithmetic $\geq$ f table $(12,404 \geq 9.27)$.
\end{abstract}

Keywords : receivable turnover, cash turnover, and liquidity.

\section{PENDAHULUAN}

Perusahaan merupakan salah satu sarana ekonomi yang dikelola secara bersama-sama untuk mencapai laba yang optimal dan memaksimalkan nilainya. Hal ini dilakukan demi menjaga serta mengembangkan kelangsungan hidupnya. perusahaan yang berhasil adalah perusahaan yang memiliki manajemen yang mampu melihat kemungkinan dan kesempatan di masa yang akan datang, baik jangka pendek atau pun jangka panjang agar tujuan perusahaan tercapai. Peranan pembelanjaan merupakan hal yang sangat penting, karena berkaitan dengan masalah modal kerja. Modal kerja atau juga sangat penting, karena digunakan sebagai sarana penunjang dalam melaksanakan operasional perusahaan. Modal kerja tersebut akan berputar terus selama perusahaan masih beroperasi yaitu sejak perusahaan didirikan 
dan akan berakhir sampai perusahaan tersebut dilikuidasi atau dibubarkan. oleh karena itu perlu diperhatikan cara mengelola modal kerja dengan baik, untuk melancarkan operasional perusahaan. Modal kerja juga merupakan ukuran tersedianya aktiva lancar yang lebih besar dari pada hutang lancar dan menunjukkan tingkat keamanan bagi kreditur jangka pendek, serta menjamin kelangsungan operasi dimasa mendatang dan kemampuan perusahaan untuk memperoleh tambahan jangka pendek dengan jaminan aktiva lancar.

Dengan semakin berkembangnya dunia usaha dewasa ini, maka persaingan antar perusahaan, khususnya antar perusahaan yang sejenis akan semakin ketat. Untuk menjaga kelangsungan hidup perusahaan dalam menghadapi persaingan yang ketat tersebut, maka diperlukan suatu penanganan dan pengelolaan sumber daya yang dilakukan oleh pihak manajemen dengan baik. Bagi pihak manajemen selain dituntut untuk dapat mengkoordinasikan penggunaan seluruh sumber daya yang dimiliki oleh perusahaan secara efisien dan efektif, juga dituntut untuk dapat menghasilkan keputusan-keputusan yang menunjang terhadap pencapaian tujuan perusahaan dimasa yang akan datang. Setiap perusahaan selalu membutuhkan modal kerja untuk membelanjai sehari-hari, misalkan untuk memberikan persekot pembelian bahan mentah, membayar upah buruh, gaji, pegawai dan lain sebagainya, di mana uang atau dana yang telah dikeluarkan itu diharapkan akan dapat kembali lagi masuk dalam perusahaan dalam waktu yang pendek melalui hasil penjualan produksinya. Uang yang masuk berasal dari penjualan produk tersebut akan segera dikeluarkan lagi untuk membiayai operasi selanjutnya. Dengan demikian maka dana tersebut akan terus menerus berputar setiap periodenya selama hidupnya perusahaan. Dalam penentuan kebijakan modal kerja yang efisien, perusahaan dihadapkan pada masalah adanya pertukaran antara faktor likuiditas dan profitabilitas. Jika perusahaan memutuskan menetapkan modal kerja dalam jumlah yang besar, kemungkinan tingkat likuiditas akan terjaga namun kesempatan untuk memperoleh laba yang besar akan menurun yang pada akhirnya berdampak pada menurunnya profitabilitas. Sebaliknya jika perusahaan ingin memaksimalkan profitabilitas, kemungkinan dapat mempengaruhi tingkat likuiditas perusahaan. Makin tinggi likuiditas, maka makin baiklah posisi perusahaan di mata kreditur. Oleh karena 
terdapat kemungkinan yang lebih besar bahwa perusahaan akan dapat membayar kewajibannya tepat pada waktunya. Di lain pihak ditinjau dari segi sudut pemegang saham, likuiditas yang tinggi tak selalu menguntungkan karena berpeluang menimbulkan dana-dana yang menganggur yang sebenarnya dapat digunakan untuk berinvestasi dalam proyek-proyek yang menguntungkan perusahaan.

PT. Ultrajaya Milk Industry \& Trading Company Tbk merupakan salah satu perusahaan yang cukup terkemuka di bidang industri makanan dan minuman. Khususnya minuman yang di produksi dengan teknologi UHT (Ultra High Temperature) dan dikemas dalam kemasan karton aseptik. Dibidang makanan perseroan memperoduksi mentega (butter), susu bubuk (powder milk), dan susu kental manis (sweetned condensed milk). Dibidang minuman perseroan memperoduksi rupa-rupa jenis minuman seperti minuman susu, sari buah, teh, minuman tradisional dan minuman untuk kesehatan.

Kaitannya dengan pembahasan di atas dan dalam rangka meningkatkan kinerja perusahaan, PT Ultrajaya Milk Industry \& Trading Company Tbk. perlu menyadari adanya pengukuran kinerja keuangan yang baik dengan salah satu cara menilai kinerja keuangan dari sisi rasio diantaranya:

Perputaran kas merupakan periode berputarnya kas yang dimulai pada saat kas di investasikan dalam komponen modal kerja sampai saat kembali menjadi kaskas sebagai unsur modal kerja yang paling tinggi likuiditasnya. Menurut Rahma (2011) menyatakan bahwa perputaran kas menunjukan kemampuan kas dalam menghasilkan pendapatan, sehingga dapat dilihat berapa kali uang kas berputar dalam satu periode tertentu. Semakin tinggi perputaran kas perusahaan akan semakin baik, ini berarti semakin tinggi efisiensi penggunaanya kas dan keuntungan yang diperoleh semakin besar sehingga dapat mempengaruhi kinerja keuangan perusahaan.

Piutang sebagai unsur modal kerja dalam kondisi berputar, yaitu dari kas, proses komoditi, penjualan, piutang, kembali ke kas. Makin cepat perputaran piutang makin baik kondisi keuangan perusahaan. Perputaran piutang (receivable turnover) dapat disajikan dengan perhitungan : penjualan bersih secara kredit di bagi rata-rata 
piutang. Kemudian 360 hari dibagi perputaran piutang menghasilkan hari rata-rata pengumpulan piutang (average collection period of accounts receivable).

Rasio likuiditas adalah rasio yang mengukur kemampuan PT Ultrajaya Milk Industry \& Trading Company tbk. Untuk membayar kewajiban-kewajibannya yang harus dipenuhi (kewajiban jangka pendek) dengan menggunakan asset yang dimilikinya.

Tabel 1

Perputaran Piutang, Perputaran Kas, Dan Likuiditas (Current Ratio) PT. Ultrajaya Milk Industry \& Trading Company Tbk.

\begin{tabular}{|l|c|c|c|}
\hline Tahun & $\begin{array}{c}\text { Perputaran } \\
\text { Piutang }\end{array}$ & $\begin{array}{c}\text { Perputaran } \\
\text { Kas }\end{array}$ & $\begin{array}{c}\text { Likuiditas } \\
\text { (CR) }\end{array}$ \\
\hline 2005 & 6,0 & 6,8 & 1,6 \\
\hline 2006 & 6,7 & 13,7 & 1,2 \\
\hline 2007 & 7,9 & 19,6 & 2,4 \\
\hline 2008 & 8,7 & 13,4 & 1,9 \\
\hline 2009 & 9,8 & 8,5 & 2,1 \\
\hline 2010 & 10,3 & 6,3 & 2,0 \\
\hline 2011 & 9,4 & 6,7 & 1,5 \\
\hline 2012 & 10,2 & 7,2 & 2,0 \\
\hline 2013 & 10,4 & 6,0 & 2,5 \\
\hline 2014 & 10,3 & 7,1 & 3,3 \\
\hline
\end{tabular}

Sumber : Data Diolah

Berdasarkan hasil perhitungan, diketahui bahwa perputaran piutang dan perputaran kas, terhadap likuditas selama sepuluh tahun mengalami fluktuasi. Secara keseluruhan perputaran piutang tertinggi pada tahun 2013, sebesar 10,4 kali. Makin cepat perputaran piutang perusahaan makin baik pula kondisi keuangan perusahaan. Perputaran kas tertinggi pada tahun 2007, sebesar 19,6 kali dan likuiditas tertinggi sebesar 3,3 kali di tahun 2014.

Berdasarkan pemaparan diatas dengan melihat data yang ada, maka dari itu penulis sangat tertarik untuk meneliti hal-hal tersebut yang dapat dijadikan sebagai bahan skripsi dengan judul "Pengaruh Perputaran Piutang dan Perputaran Kas terhadap likuiditas PT. Ultrajaya Milk Industry \& Trading Company Tbk." 
Pokok permasalahan dalam penelitian ini akan dirumuskan sebagai berikut : (a) Bagaimana perputaran piutang PT Ultrajaya Milk Industry \& Trading Company Tbk? (b) Bagaimana perputaran kas PT Ultrajaya Milk Industry \& Trading Company Tbk? (c) Bagaimana likuiditas PT Ultrajaya Milk Industry \& Trading Company Tbk? (d) Bagaimana pengaruh perputaran piutang terhadap likuiditas pada PT Ultrajaya Milk Industry \& Trading Company Tbk? (e) Bagaimana pengaruh perputaran kas terhadap likuiditas pada PT Ultrajaya Milk Industry \& Trading Company Tbk? (f) Bagaimana pengaruh perputaran piutang dan perputaran kas secara bersama-sama terhadap likuiditas pada PT Ultrajaya Milk Industry \& Trading Company Tbk?.

\section{TELAAH LITERATUR DAN PENGEMBANGAN HIPOTESIS}

\section{Perputaran Piutang}

Piutang merupakan elemen modal kerja yang selalu dalam keadaan berputar. Periode perputaran piutang ini dimulai pada saat kas dikeluarkan untuk mendapatkan persediaan kemudian persediaan tersebut dijual dengan cara kredit sehingga akan menimbulkan piutang dimana piutang tersebut akan berubah kembali menjadi kas pada saat terjadi pelunasan piutang tersebut oleh para pelanggannya.

Jumlah piutang biasanya melahirkan hubungan erat dengan volume penjualan kredit. Posisi piutang dan waktu penarikan yang tepat mungkin dievaluasi dengan perhitungan perputaran piutang. Tingkat yang ditentukan dengan membagi penjualan kredit bersih (bukan total penjualan bersih jika penjualan kredit belum diketahui) dengan piutang dagang perdagangan rata-rata yang selama tahun itu, dalam mengembangkan jumlah piutang rata-rata, saldo bulanan seharusnya digunakan jika tersedia.

Menurut Lukman Syamsudin (2007:254) mengatakan bahwa perputaran piutang adalah rasio perbandingan antara jumlah penjualan kredit selama periode tertentu dengan piutang rata-rata (piutang awal + piutang akhir dibagi dua) 
Dari definisi diatas dapat disimpulkan bahwa perputaran piutang adalah perbandingan antara jumlah penjualan kredit dengan piutang rata-rata selama periode tertentu.

Darsono (2006:95) piutang sebagai unsur modal kerja dalam kondisi berputar yaitu dari kas, proses komoditi, penjualan, piutang, kembali ke kas. Makin cepat perputaran piutang makin baik kondisi keuangan perusahaan. Perputaran piutang (receivable turnover) dapat disajikan dengan perhitungan penjualan bersih secara kredit dibagi rata-rata piutang. Kemudian 360 hari dibagi perputaran piutang menghasilkan hari rata-rata pengumpulan piutang (average colletion period of account receivable).

Rumus :

$$
\begin{aligned}
& \text { perputaran piutang }=\frac{\text { penjualan } \text { kredit }}{\text { rata }- \text { rata piutang }} \\
& \text { rata }- \text { rata pengumpulan piutang }=\frac{360 \text { hari }}{\text { perputaran piutang }} \\
& \text { receivable turnover }=\frac{\text { net credit sales }}{\text { average receivable }} \\
& \text { average receivable }=\frac{\text { piutang awal }+ \text { piutang akhir }}{2}
\end{aligned}
$$

Tingkat perputaran piutang dapat digunakan sebagai gambaran keefektifan pengelolaan piutang, karena semakin tinggi tingkat perputaran piutang suatu perusahaan berarti semakin baik pengelolaan piutangnya. Tingkat perputaran piutang dapat dipertinggi dengan jalan memperketat kebijakan penjualan kredit misalnya dengan jalan memperpendek jangka waktu pembayaran. Keefektifan penjualan kredit suatu perusahaan tidak cukup dilihat dari tingkat perputaran piutang, tetapi juga perlu dikaitkan dengan hari rata-rata pengumpulan piutang.

Makin tinggi perputaran piutang menunjukan modal kerja yang ditanamkan dalam piutang rendah, sebaliknya apabila rasio perputaran rendah maka makin terjadi over estimate. Penurunan rasio perputaran piutang menurut Munawir (2009:75) dapat disebabkan beberapa faktor yaitu:

a. Turunnya penjualan dan naiknya piutang.

b. Turunnya piutang dan diikuti turunnya penjualan dalam jumlah besar. 
c. Naiknya penjualan diikuti oleh naiknya piutang dalam jumlah yang lebih besar.

d. Turunnya penjualan dengan piutang tetap.

e. Naiknya piutang sedangkan penjualan tidak berubah.

Penurunan rasio perputaran piutang juga dapat disebabkan karena bagian kredit dan penagihan tidak bekerja dengan efektif atau mungkin ada perubahan dalam kebijakan pemberian kredit.

\section{Perputaran Kas}

Kas merupakan aktiva yang paling likuid untuk memenuhi kebutuhan perusahaan. Makin besar kas yang ada dalam perusahaan berarti makin tinggi likuiditasnya. Menurut Munawir (2010:14) kas adalah uang tunai yang dapat digunakan untuk membiayai operasi perusahaan. Menurut Bambang Riyanto (2011:94) kas adalah salah satu unsur modal kerja yang paling tinggi tingkat likuiditasnya. Sedangkan Menurut Sutrisno (2013:9) kas merupakan suatu alat pertukaran dan juga digunakan sebagai ukuran dalam akuntansi dalam neraca, kas merupakan aktiva yang paling lancar, dalam arti piutang sering berubah, hampir pada setiap transaksi dengan pihak luar selalu mempengruhi kas. Penerimaan kas suatu perusahaan berasal dari dua sumber utama yaitu penerimaan kas dari penjualan tunai, dan penerimaan piutang (penjualan kredit). Sumber penerimaan kas yang berasal dari penjualan tunai atau penjualan kredit antara lain, yaitu:

a. Penerimaan kas dari pelanggan.

b. Penerimaan kas dari bunga.

c. Penjualan aktiva tetap.

d. Penjualan investasi yang bukan ekuivalen kas.

e. Penerimaan kas atas pinjaman yang diberikan.

f. Pengeluaran saham.

g. Penjualan saham perbendaharaan.

h. Pinjaman uang.

Faktor-faktor yang mempengaruhi ketersediaan kas bisa melalui penerimaan dan pengeluaran kas. Menurut Bambang Riyanto (2011:346) mengatakan bahwa 
perubahan yang efeknya menambah dan mengurangi kas dan dikatakan sebagai sumber-sumber penerimaan dan pengeluaran kas adalah sebagai berikut:

a. Berkurang dan bertambahnya aktiva lancar selain kas

Berkurangnya aktiva lancar selain kas berarti bertambahnya dana atau kas, hal ini dapat terjadi karena terjualnya barang tersebut, dan hasil penjualan tersebut merupakan sumber dana atau kas bagi perusahaan itu. Bertambahnya aktiva lancar dapat terjadi karena pembelian barang, dan pembelian barang membutuhkan dana.

b. Berkurang dan bertambahnya aktiva tetap

Berkurangnya aktiva tetap berarti bahwa sebagian dari aktiva tetap itu dijual dan hasil penjualannya merupakan sumber dana dan menambah kas perusahaan. Bertambahnya aktiva tetap dapat terjadi karena adanya pembelian aktiva tetap dengan menggunakan kas. Penggunaan kas tersebut mengurangi jumlah kas perusahaan.

c. Bertambah dan berkurangnya setiap jenis hutang

Bertambahnya hutang, baik hutang lancar maupun hutang jangka panjang berarti adanya tambahan kas yang diterima oleh perusahaan. Berkurangnya hutang, baik hutang lancar maupun hutang jangka panjang dapat terjadi karena perusahaan telah melunasi atau mengangsur hutangnya dengan menggunakan kas sehingga mengurangi jumlah kas.

d. Bertambahnya modal

Bertambahnya modal dapat menambah kas misalnya disebabkan karena adanya emisi saham baru, dan hasil penjualan saham baru. Berkurangnya modal dengan mengguankan kas dapat terjadi karena pemilik perusahaan mengambil kembali atau mengurangi modal yang tertanam dalam perusahaan sehingga jumlah kas berkurang.

e. Adanya keuntungan dan kerugian dari operasi perusahaan

Apabila perusahaan mendapatkan keuntungan dari operasinya berarti terjadi penambahan kas bagi perusahaan yang bersangkutan sehingga penerimaan kas perusahaan pun bertambah. Timbulnya kerugian selama periode tertentu dapat menyebabkan ketersedian kas berkurang karena perusahaan memerlukan 
kas untuk menutup kerugian. Dengan kata lain, pengeluaran kas bertambah sehingga ketersediaan kas menjadi berkurang.

Tingkat perputaran kas merupakan ukuran efisiensi penggunaan kas yang dilakukan oleh perusahaan. Karena tingkat perputaran kas menggambarkan kecepatan arus kas kembalinya kas yang telah ditanamkan didalam modal kerja. Dalam mengukur tingkat perputaran kas yang telah tertanam dalam modal kerja adalah berasal dari aktivitas operasional perusahaan. Menurut Bambang Riyanto (2011:95) perputaran kas adalah perbandingan antara penjualan dengan jumlah penjualan atau salesnya. Perbandingan antara sale dengan jumlah kas rata-rata menggambarkan tingkat perputaran kas (cash turn over). Semakin tinggi tingkat perputaran kas berarti semakin cepat kembalinya kas masuk pada perusahaan. Dengan demikian kas akan dapat dipergunakan kembali untuk membiayai kegiatan operasional sehingga tidak mengganggu kondisi keuangan perusahaan.

$$
\begin{aligned}
& \text { perputaran kas }=\frac{\text { penjualan bersih }}{\text { rata }- \text { rata kas }} \\
& \text { rata }- \text { rata } \text { kas }=\frac{\text { kas awal }+ \text { kas akhir }}{2}
\end{aligned}
$$

\section{Likuiditas}

Ketidakmampuan perusahaan membayar kewajibannya terutama utang jangka pendek (yang sudah jatuh tempo) disebabkan oleh berbagai faktor. Pertama, bisa dikarenakan memang perusahaan sedang tidak memiliki dana sama sekali atau kedua, bisa mungkin saja perusahaan memiliki dana, namun saat jatuh tempo perusahaan tidak memiliki dana (tidak cukup) secara tunai sehingga harus menunggu dalam waktu tertentu untuk mencairkan aktiva lainnya seperti menagih piutang, menjual surat-surat berharga, atau menjual persediaan atau aktiva lainnya. Tingkat kemampuan suatu perusahaan untuk dapat membayar utang-utang jangka pendeknya sering disebut sebagai likuiditas. Perusahaan yang mempunyai cukup kemampuan untuk membayar utang jangka pendek disebut perusahaan yang likuid sedangkan perusahaan yang berada dalam ketidakmampuan membayar utang jangka pendek yang cukup disebut perusahaan yang ilikuid. 
Menurut Kasmir (2012:145) rasio likuiditas adalah kemampuan perusahaan dalam membiayai dan memenuhi kewajiban atau utang pada saat ditagih jatuh tempo. Menurut Brigham dan Houston dalam bukunya "dasar-dasar manajemen keuangan" (2010:134), mengatakan bahwa: "asset likuid merupakan asset yang diperdagangkan dipasar aktif sehingga dapat dikonversi dengan cepat menjadi kas pada harga pasar yang berlaku, sedangkan posisi likuiditas suatu perusahaan berkaitan dengan pertanyaan, apakah perusahaan mampu melunasi utangnya ketika utang tersebut jatuh tempo ditahun berikutnya."

Pengertian likuditas menurut Fred Weston dalam Kasmir (2012:129) adalah: "rasio yang menggambarkan kemampuan perusahaan memenuhi kewajiban (utang) jangka pendek. Artinya apabila perusahaan ditagih, maka akan mampu memenuhi utang (membayar) tersebut terutama utang yang udah jatuh tempo.”

Dari pengertian menurut para ahli diatas dapat ditarik kesimpulan likuiditas adalah kemampuan perusahaan untuk memenuhi kewajiban atau utang jangka pendek yang sudah jatuh tempo.

Menurut Dewi Astuti (2008:161) perubahan likuiditas dipengaruhi oleh beberapa faktor yaitu:

a. Tingkat likuiditas akan naik jika :

1) Aktiva lancar naik dan hutang lancar tetap atau turun.

2) Aktiva lancar naik dan hutang lancar naik dengan persentase yang lebih kecil.

3) Aktiva lancar turun dan hutang lancar turun dengan persentase yang lebih besar.

4) Aktiva lancar tetap dan hutang lancar naik.

b. Tingkat likuiditas akan turun jika :

1) Aktiva lancar naik dan hutang lancar naik dengan persentase yang lebih besar.

2) Aktiva lancar turun dan hutang lancar tetap atau naik.

3) Aktiva lancar turun dan hutang lancar turun dengan persentase yang lebih besar.

4) Aktiva lancar dan hutang lancar naik. 
c. Tingkat likuiditas akan tetap jika :

1) Aktiva lancar dan hutang lancar tetap.

2) Aktiva lancar dan hutang lancar naik atau turun dengan persentase yang sama.

Rasio likuiditas (Current Ratio):

Rasio yang digunakan untuk mengukur kemampuan perusahaan menurut Miswanto dan Eko Widodo (2008:83) current ratio adalah perbandingan antara aktiva lancar dan hutang lancar.

$$
\text { current ratio }=\frac{\text { aktiva lancar }}{\text { hutang lancar }} \times 100 \%
$$

\section{Pengembangan Hipotesis}

Berikut bagan kerangka pemikiran dalam penelitian ini :

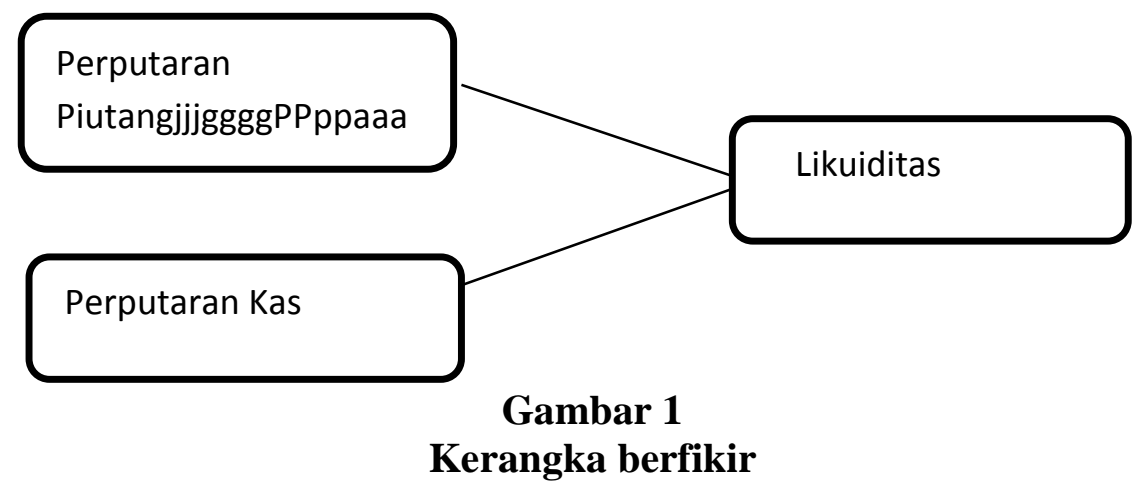

Populasi adalah semua nilai baik hasil perhitungan maupun hasil pengukuran. Baik kuantitatif maupun kualitatif, dari pada karakteristik tertentu mengenai sekelompok objek yang lengkap dan jelas. Menurut Burhan Bungin (2009:99), dalam metode penelitian kata populasi amat popular, digunakan untuk menyebutkan serumpun, atau sekelompok objek yang menjadi sasaran penelitian. Menurut Sugiyono (2011:80) populasi merupakan suatu wilayah suatu generalisasi yang terdiri atas: objek/subjek yang mempunyai kualitas dan karakteristik tertentu yang ditetapkan oleh peneliti untuk dipelajari dan kemudian ditarik kesimpulannya. Populasi dari penelitian ini meliputi laporan keuangan PT Ultrajaya Milk Industry \& Trading Company Tbk. 
Sampel merupakan bagian dari populasi yang diambil melalui cara-cara tertentu yang juga dimiliki karakteristik tertentu, jelas, dan lengkap yang dianggap bisa mewakili populasi. Sampel dalam penelitian ini meliputi laporan keuangan perusahaan tahun 2005-2014 berupa balance sheet (neraca) dan laporan laba rugi.

Hipotesis penelitian merupakan dugaan atau jawaban sementara terhadap identifikasi masalah penelitian. Dengan demikian hipotesis juga dapat dinyatakan sebagai jawaban teoritis terhadap identifikasi masalah penelitian.

Berdasarkan kerangka di atas, maka penulis memberikan hipotesis sebagai berikut:

$\mathrm{H}_{0} 1$ = tidak terdapat pengaruh perputaran piutang terhadap likuiditas perusahaan.

$\mathrm{H}_{\mathrm{a}} \mathrm{l} \quad=$ terdapat pengaruh perputaran piutang terhadap likuiditas perusahaan.

$\mathrm{H}_{0} 2$ = tidak terdapat pengaruh perputaran kas terhadap likuiditas perusahaan.

$\mathrm{H}_{\mathrm{a}} 2$ = terdapat pengaruh perputaran kas terhadap likuiditas perusahaan.

$\mathrm{H}_{0} 3$ = tidak terdapat pengaruh perputaran piutang dan perputaran kas terhadap likuiditas perusahaan.

$\mathrm{H}_{\mathrm{a}} 3$ = terdapat pengaruh perputaran piutang dan perputaran kas terhadap likuiditas perusahaan.

\section{METODE PENELITIAN DAN PEMBAHASAN}

Adapun sifat penelitian ini bersifat deskriptif kuantitatif. Metode deskriptif adalah suatu metode dalam meneliti status sekelompok manusia, suatu objek, suatu kondisi, suatu sistem pemikiran pada masa sekarang

Data yang digunakan dalam penelitian ini adalah data sekunder. Menurut Mudrajad Kuncoro (2009:148) data sekunder adalah data yang telah dikumpulkan oleh lembaga pengumpul data dan dipublikasikan kepada masyarakat pengguna data. Data yang digunakan dalam penelitian ini diperoleh dari data skunder yang diambil dari Bursa Efek Indonesia. Data yang digunakan terdiri dari :

1) Laporan neraca PT. Ultrajaya Milk Industry \& Trading Company Tbk. tahun 2005-2014 
2) Laporan laba rugi PT. Ultrajaya Milk Industry \& Trading Company Tbk. tahun 2005-2014.

Menurut Sugiyono (2012:38) variabel penelitian pada dasarnya adalah segala sesuatu yang berbentuk apa saja yang ditetapkan oleh peneliti untuk dipelajari sehingga diperoleh informasi tentang hal tersebut, kemudian ditarik kesimpulan.

Variabel-variabel yang berperan dalam penelitian ini adalah hanya pada analisis perputaran piutang dan perputaran kas dihubungkan dengan likuiditas. Untuk lebih memperjelas variabel yang akan diuji, maka dibawah ini dijelaskan variabel-variabel tersebut:

\section{Variabel Bebas (Independent Variabel)}

Variabel bebas merupakan variabel yang mempengaruhi atau yang menjadi sebab perubahan atau timbulnya variabel dependen (terikat). Variabel bebas yang digunakan dalam penelitian ini adalah perputaran piutang dan perputaran kas PT Ultrajaya Milk Industry \& Trading Company Tbk.

2. Variabel Terikat (Dependen Variabel)

Variabel terikat merupakan variabel yang dipengaruhi atau yang menjadi akibat karenanya adanya variabel bebas. Variabel terikat dalam penelitian ini adalah Likuiditas. Likuiditas yang dibahas dalam penelitian ini menggunakan rumus current ratio. Atau dengan kata lain bahwa likuiditas adalah kemampuan suatu perusahaan untuk memenuhi kebutuhan utang ketika jatuh tempo. Rumus yang digunakan :

$$
\text { current ratio }=\frac{\text { current asset }}{\text { current liabilities }} \times 100 \%
$$

Dalam hal ini likuiditas akan diperhitungkan perbandingannya dari setiap periode menggunakan rumus yang telah ditetapkan, dengan pengambilan periode waktu perhitungan data laporan keuangan dari tahun 2005-2014, laporan keuangan yang diambil hanya dari neraca dan laporan laba rugi.

\section{Uji normalitas}

Uji normalitas bertujuan untuk menguji apakah dalam model regresi, variabel pengganggu atau residual memiliki distribusi normal. Dalam uji normalitas 
terdapat dua cara untuk mendeteksi apakah residual berdistribusi normal atau tidak yaitu dengan analisis grafik dan uji statistik (Imam Ghozali,2005:110). Penyajian Normal Probability dapat disajikan sebagai berikut :

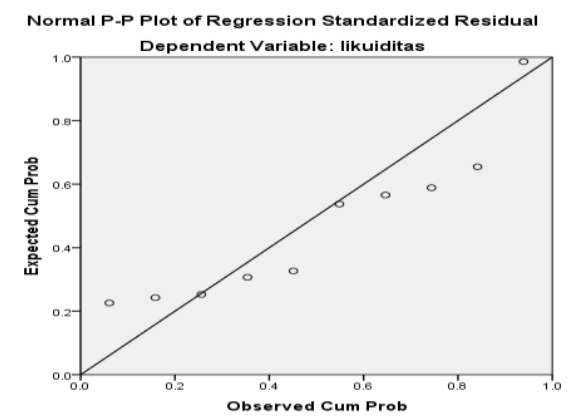

Gambar 2

Pengujian normal probability

Menurut Singgih Santoso (2008:214) ada beberapa cara mendeteksi normalitas dengan melihat penyebaran data (titik) pada sumbu diagonal dan grafik. Dasar pengambilan keputusan:

1) Jika data menyebar di sekitar garis diagonal dan mengikuti arah garis diagonal,maka model regresi memenuhi asumsi normalitas.

2) Jika data menyebar jauh dari garis diagonal dan atau tidak mengikuti arah garis diagonal, maka model regresi tidak memenuhi asumsi normalitas.

Dari Gambar 4.2 dapat dilihat bahwa data menyebar disekitar garis diagonal dan mengikuti arah garis diagonal, maka model regresi memenuhi asumsi normalitas. Sedangkan pengujian menggunakan uji kolmogrov-Smirnov dapat di sajikan sebagai berikut:

Tabel 2

Uji kolmogrov-Smirnov

One-Sample Kolmogorov-Smirnov Test

\begin{tabular}{|ll|r|}
\hline & & $\begin{array}{c}\text { Unstandardized } \\
\text { Residual }\end{array}$ \\
\hline Normal Parameters ${ }^{\mathrm{a}, \mathrm{b}}$ & Mean & 10 \\
& Std. & .0000000 \\
& Deviation & 3.92713244 \\
Most Extreme Differences & Absolute & .226 \\
& Positive & .226 \\
& Negative & -.197
\end{tabular}




\begin{tabular}{l|l} 
Test Statistic & .226 \\
Asymp. Sig. (2-tailed) & $.160^{c}$ \\
\hline
\end{tabular}

Kriteria Pengambilan keputusan yaitu jika Signifikansi > 0,05 maka data berdistribusi normal, dan jika Signifikansi $<0,05$ maka data tidak berdistribusi normal menurut Dwi Priyatno (2013:58). Dari hasil diatas dapat ditarik kesimpulan nilai test statistik 0,226 dan asymp.sig (2 tailed) memiliki nilai signifikansi sebesar 0,160. Karena signifikansi lebih besar dari 0,05, maka dapat disimpulkan data berdistribusi normal.

\section{Uji Multikolinieritas}

Uji multikolinieritas bertujuan untuk menguji apakah model regresi ditemukan adanya korelasi antar variabel bebas (independen), (Imam Ghozali, 2005:91). Multikolinieritas merupakan keadaan di mana satu atau lebih variabel independen dinyatakan kondisi linier dengan variabel lainnya. Artinya jika di antara pengubah-pengubah bebas digunakan sama sekali tidak berkorelasi satu dengan yang lain maka bisa dikatakan tidak terjadi multikolinieritas.

Tabel 3

\section{Uji multikolinieritas}

Coefficients ${ }^{\mathrm{a}}$

\begin{tabular}{|c|c|c|c|c|c|c|c|c|}
\hline & & $\begin{array}{r}\text { Unstan } \\
\text { Coeff }\end{array}$ & $\begin{array}{l}\text { ardized } \\
\text { cients }\end{array}$ & $\begin{array}{l}\text { Standardized } \\
\text { Coefficients }\end{array}$ & & & \multicolumn{2}{|c|}{ Collinearity Statistics } \\
\hline \multicolumn{2}{|c|}{ Model } & B & Std. Error & Beta & $\mathrm{T}$ & Sig. & Tolerance & VIF \\
\hline \multirow[t]{2}{*}{1} & (Constant) & -44.362 & 13.034 & & -3.404 & .011 & & \\
\hline & $\begin{array}{l}\text { prptran_piutn } \\
\mathrm{g}\end{array}$ & .587 & .118 & 1.031 & 4.973 & .002 & .731 & 1.368 \\
\hline
\end{tabular}




\begin{tabular}{|l|l|r|r|r|r|r|r|r|}
\hline & prptran_kas & .108 & .038 & .586 & 2.823 & .026 & .731 & 1.368 \\
\hline
\end{tabular}

a. Dependent Variable: likuiditas

Untuk menguji asumsi multikolinieritas dapat digunakan VIF (Vareance Infation Factor) dan TOL (tolerance), dimana (Imam Ghozali, 2006:91), mengatakan bahwa:

1) Bila nilai tolerance $>0,10$ dan $\mathrm{VIF}<10$, maka dapat diartikan bahwa tidak terdapat multikolinieritas pada penelitian tersebut.

2) Bila nilai tolerance $<0,10$ dan VIF $>10$, maka dapat diartikan bahwa terjadi gangguan multikolinieritas pada penelitian tersebut.

Dari tabel 3 diatas dapat diketahui angka tolerance value lebih dari 0,1 (perputaran piutang 0,731 dan perputaran kas 0,731). Dan nilai VIF (perputaran piutang 1,368 dan perputaran kas 1,368) kurang dari 10. Jadi dapat disimpulkan bahwa dalam model regresi tidak terjadi masalah multikolinearitas.

\section{Uji heteroskedastisitas}

Menurut Ghozali (2006), pengujian ini bertujuan untuk menguji apakah dalam model regresi ini terjadi ketidaksamaan varian dari residual satu pengamatan ke pengamatan lain. Jika varian dari residual satu pengamatan ke pengamatan yang lain tetap, maka disebut homoskedastisitas dan jika berbeda disebut heteroskedasitas. Model yang baik adalah homoskedastisitas dan tidak terjadi heteroskedasitas. Sceterplot dapat dilihat pada output regresi dan disajikan sebagai berikut :

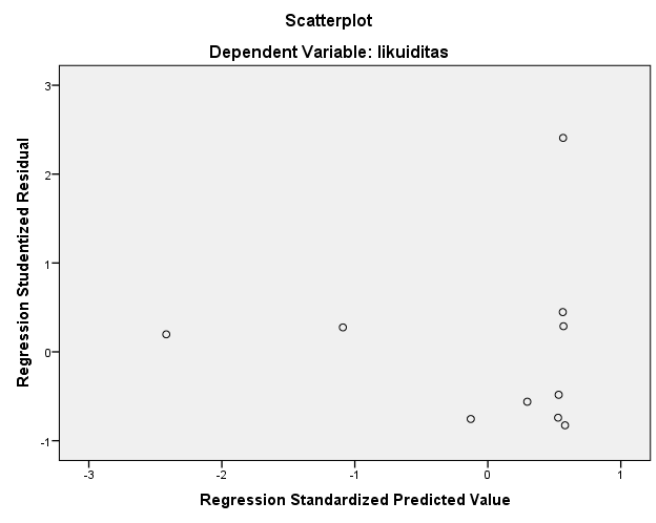

Gambar 3

Uji heteroskedastisitas 
Dari scatterplot diatas terlihat bahwa titik-titik menyebar secara acak dan tidak membentuk pola, serta titik-titik menyebar dibawah dan diatas angka 0 pada sumbu Y. Sehingga dapat disimpulkan tidak terjadi masalah heteroskedastisitas pada model regresi.

\section{Uji autokorelasi}

Uji autokorelasi bertujuan menguji apakah model regresi linier ada korelasi antara kesalahan pengganggu pada periode t-1 (sebelumnya). Jika terjadi korelasi, maka dinamakan ada problem autokorelasi. Autokorelasi muncul karena observasi yang berurutan sepanjang waktu berkaitan satu sama lain (Imam Ghazali,2005:95). Tentu saja model regresi yang baik adalah regresi yang terbebas dari autokorelasi adalah dengan uji Durbin Watson (DW).

Dasar pengambilan keputusan ada tidaknya autokorelasi dengan melihat besarnya Durbin-waston yaitu:

1) Angka DW di bawah -2 terdapat autokorelasi positif

2) Angka DW -2 sampai + 2 tidak terdapat autokorelasi

3) Angka DW diatas -2 terdapat autokorelasi negatif

\section{Tabel 4}

Uji Autokorelasi

Model Summaryb

\begin{tabular}{|l|r|r|r|r|r|}
\hline Model & $\mathrm{R}$ & R Square & \multicolumn{1}{c|}{$\begin{array}{c}\text { Adjusted R } \\
\text { Square }\end{array}$} & $\begin{array}{c}\text { Std. Error of the } \\
\text { Estimate }\end{array}$ & Durbin-Watson \\
\hline 1 & $.883^{\mathrm{a}}$ & .780 & .717 & 4.45295 & .723 \\
\hline
\end{tabular}

a. Predictors: (Constant), prptran_kas, prptran_piutng

b. Dependent Variable: likuiditas

Dari tabel 4 diatas dapat dilihat bahwa nilai D-W sebesar 0,723 hal ini menunjukan bahwa tidak terdapat autokorelasi karena angka D-W -2 sampai +2 .

\section{Analisis Regresi Linier Berganda}

Pada analisis regresi berganda bahwa regresi berganda variabel tergantung (terikat) dipengaruhi oleh dua atau lebih variabel bebas, sehingga hubungan 
fungsional antara variabel terikat $(\mathrm{Y})$ dengan variabel bebas $\left(\mathrm{X}_{1}, \mathrm{X}, \mathrm{X}_{\mathrm{n}}\right)$. Menurut (Suliyanto,2011:53). Dalam hal ini digunakan regresi linear berganda karena akan menganalisis pengaruh dari beberapa variabel independen terhadap satu variabel dependen.

Bentuk umum dari regresi linear berganda sebagai berikut:

Tabel 5

Hasil analisis regresi

Coefficients ${ }^{\mathbf{a}}$

\begin{tabular}{|c|c|c|c|c|c|c|c|}
\hline \multirow[b]{2}{*}{ Model } & \multicolumn{2}{|c|}{$\begin{array}{l}\text { Unstandardized } \\
\text { Coefficients }\end{array}$} & \multirow{2}{*}{$\begin{array}{c}\text { Standardize } \\
\text { d } \\
\text { Coefficients } \\
\text { Beta }\end{array}$} & \multirow[b]{2}{*}{$\mathrm{T}$} & \multirow[b]{2}{*}{ Sig. } & \multicolumn{2}{|c|}{$\begin{array}{l}\text { Collinearity } \\
\text { Statistics }\end{array}$} \\
\hline & B & Std. Error & & & & $\begin{array}{c}\text { Toleranc } \\
\mathrm{e}\end{array}$ & VIF \\
\hline $1 \quad$ (Constant) & -44.362 & 13.034 & & -3.404 & .011 & & \\
\hline $\begin{array}{l}\text { prptran_piut } \\
\text { ng }\end{array}$ & .587 & .118 & 1.031 & 4.973 & .002 & .731 & 1.368 \\
\hline prptran_kas & .108 & .038 & .586 & 2.823 & .026 & .731 & 1.368 \\
\hline
\end{tabular}

a. Dependent Variable: likuiditas

Dari tabel 5 diatas data yang diperoleh dapat disusun persamaan regresi linier berganda sebagai berikut : $Y=\mathbf{- 4 4 , 3 6 2 + 0 , 5 8 7} \mathrm{X}_{\mathbf{1}}+\mathbf{0 , 1 0 8 X _ { 2 }}$

Persamaan regresi diatas mempunyai arti sebagai berikut :

1) Konstanta sebesar $-44,362$ menyatakan bahwa jika variabel bebas dianggap konstan sama dengan nol(0), maka likuiditas nilainya negatif sebasar $-44,362$.

2) Koefisien regresi $X_{1}$ atau untuk variabel Perputaran Piutang adalah sebesar 0,587 menyatakan bahwa setiap penambahan Perputaran Piutang sebesar 1 kali perputaran piutang akan menaikan likuiditas sebesar 587\%. Nilai koefisien yang positif menunjukkan bahwa Perputaran Piutang berpengaruh positif pada likuiditas. 
3) Koefisien regresi $X_{2}$ atau untuk variabel Perputaran Kas adalah sebesar 0,108 menyatakan bahwa setiap penambahan Perputaran Kas sebesar 1 kali perputaran kas, akan menaikan likuiditas sebesar 108\%. Nilai koefisien yang positif menunjukkan bahwa perputaran kas berpengaruh positif pada likuiditas.

\section{Koefisien korelasi linier berganda}

Koefisien korelasi linier berganda ini berfungsi untuk mengukur derajat linier $X_{1}$ dan $X_{2}$ terhadap $Y$, menurut Sugiyono (2011:191). Hasil perhitungan koefisien korelasi penelitian dapat dilihat pada tabel 4.12 sebagai berikut :

\section{Tabel 6}

Uji korelasi

Model Summary

\begin{tabular}{|l|r|r|r|r|r|}
\hline Model & \multicolumn{1}{|c|}{$\mathrm{R}$} & R Square & \multicolumn{1}{c|}{$\begin{array}{c}\text { Adjusted R } \\
\text { Square }\end{array}$} & $\begin{array}{c}\text { Std. Error of the } \\
\text { Estimate }\end{array}$ & Durbin-Watson \\
\hline 1 & $.883^{\mathrm{a}}$ & .780 & .717 & 4.45295 & .723 \\
\hline
\end{tabular}

a. Predictors: (Constant), prptran_kas, prptran_piutng

b. Dependent Variable: likuiditas

Dari hasil perhitungan diperoleh nilai koefisien korelasi adalah 0,883 . Hal ini berarti tingkat hubungan korelasi antara variabel perputaran piutang dan perputaran kas terhadapat likuiditas sangat kuat, sesuai pendapat (sugiyono, 2011 : 184) dengan penilaian 0,80-1,000.

\section{Uji Parsial (Uji Statistik t)}

Menurut Mudrajad (2009:238) Uji statistik t pada dasarnya menunjukan seberapa jauh pengaruh satu variabel penjelas secara individual dalam menerangkan variasi variabel terikat. Oleh karena itu uji t ini menggunakan untuk menguji hipotesis Ha1, Ha2, dan Ha3.

\section{Tabel 7}

Uji t

Coefficients $^{\mathrm{a}}$ 


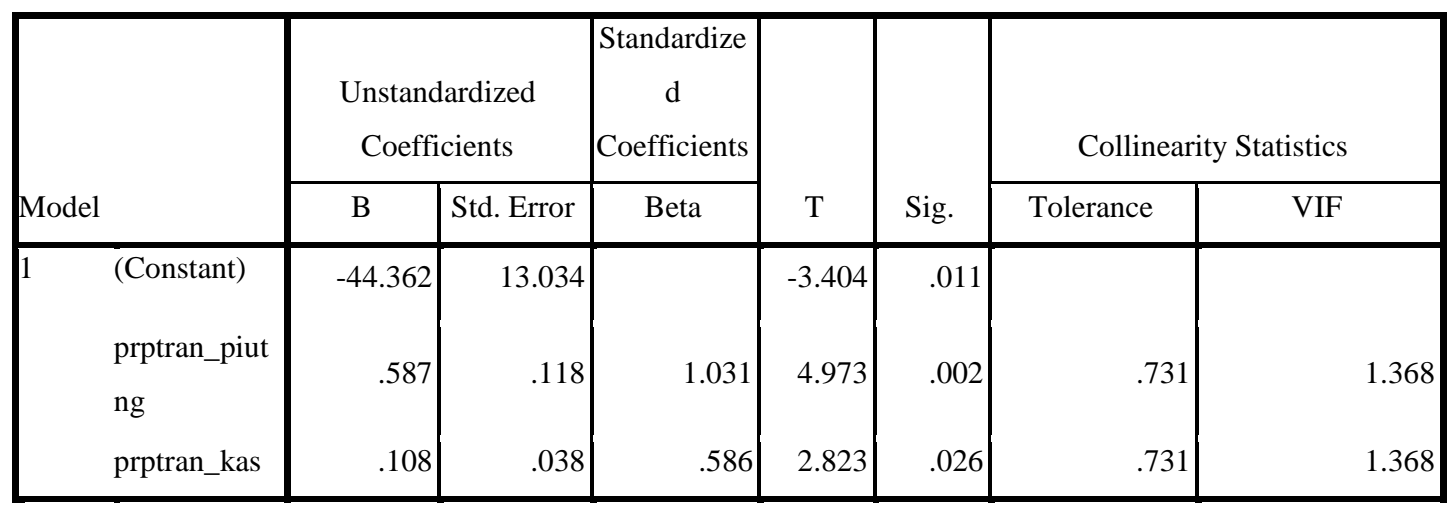

a. Dependent Variable: likuiditas

Berdasarkan hasil uji t yang ditunjukkan pada tabel 7 diperoleh hasil sebagai berikut :

1) Uji Variabel Perputaran Piutang $\left(X_{1}\right)$

Berdasarkan hasil uji t pada tabel 4.13 t hitung untuk perputaran piutang sebesar 4,973. Dan t kritis dapat dicari pada tabel statistik pada signifikansi 0,05/2=0,025 (uji 2 sisi) dengan $\mathrm{df}=\mathrm{n}-\mathrm{k}-1$ atau $\mathrm{df}=7-3-1=3$ ( $\mathrm{k}$ adalah jumlah variabel independen). Maka di dapat t kritis adalah 3,182. Maka dapat diketahui bahwa t hitung $(4,973)>\mathrm{t}$ kritis $(3,182)$ jadi hipotesis nol ditolak, kesimpulannya perputaran piutang berpengaruh terhadap likuiditas.

Dengan melihat nilai signifikansi diperoleh nilai signifikansi perputaran piutang $0,002 \leq 0,05$, sehingga variabel dependen perputaran piutang mempengaruhi variabel independen likuiditas. Nilai Koefisien dan $\mathrm{t}$ hitung adalah positif sehingga perputaran piutang berpengaruh positif terhadap likuiditas.

2) Uji Variabel Perputaran Kas $\left(X_{2}\right)$

Berdasarkan hasil uji t pada tabel 4.13 t hitung untuk perputaran kas sebesar 2,823. Dan t kritis dapat dicari pada tabel statistik pada signifikansi $0,05 / 2=0,025$ (uji 2 sisi) dengan $\mathrm{df}=\mathrm{n}-\mathrm{k}-1$ atau $\mathrm{df}=7-3-1=3$ ( $\mathrm{k}$ adalah jumlah variabel independen). Maka di dapat $\mathrm{t}$ kritis adalah 3,182. Maka dapat diketahui bahwa $\mathrm{t}$ hitung $(2,823) \leq \mathrm{t}$ kritis $(3,182)$ jadi hipotesis nol diterima, kesimpulannya perputaran kas tidak berpengaruh terhadap likuiditas. 
Dengan melihat signifikansi diperoleh nilai signifikansi perputaran piutang $0,026<0,05$, sehingga variabel dependen perputaran piutang mempengaruhi variabel independen likuiditas.

\section{Uji Simultan (Uji Statistik f)}

Menurut mudrajat (2009:239) uji statistik F pada dasarnya menunjukan apakah semua variabel bebas yang terdapat dalam model mempunyai pengaruh secara bersama-sama terhadap variabel terikat.

\section{Tabel 8}

Uji f

ANOVA ${ }^{a}$

\begin{tabular}{|c|c|c|c|c|c|c|}
\hline \multicolumn{2}{|c|}{ Model } & $\begin{array}{l}\text { Sum of } \\
\text { Squares }\end{array}$ & Df & Mean Square & $\mathrm{F}$ & Sig. \\
\hline \multirow[t]{3}{*}{1} & Regression & 491.923 & 2 & 245.961 & 12.404 & $.005^{\mathrm{b}}$ \\
\hline & Residual & 138.801 & 7 & 19.829 & & \\
\hline & Total & 630.724 & 9 & & & \\
\hline
\end{tabular}

a. Dependent Variable: likuiditas

b. Predictors: (Constant), prptran_kas, prptran_piutng

Dari tabel 8, F hitung adalah 12,404 (lihat pada tabel ANOVA). F kritis dapat dicari pada tabel statistik pada signifikansi 0,05 , df $1=\mathrm{k}-1$ atau $4-1=3$, dan df2 $=\mathrm{n}-\mathrm{k}$ atau 7-4 = 3 ( $\mathrm{K}$ adalah jumlah variabel). Di dapat $\mathrm{F}$ kritis adalah 9,27. dapat diketahui bahwa $\mathrm{f}$ hitung $(12,404) \geq \mathrm{F}$ tabel $(9,27)$ jadi H0 ditolak, kesimpulannya yaitu perputaran piutang dan perputaran kas secara serentak berpengaruh terhadap likuiditas.

\section{Koefisien Determinasi}

Cara ini digunakan untuk memberikan interprestasi dari $r$, yaitu untuk mengetahui seberapa besar pengaruh (dalam \%) variabel perputaran piutang dan perputaran kas terhadap likuiditas. Hal ini dapat terlihat pada table 4.16 sebaga berrikut : 


\section{Tabel 9}

Uji Determinasi

Model Summary

\begin{tabular}{l|r|r|r|r|r|}
\hline Model & $\mathrm{R}$ & R Square & $\begin{array}{c}\text { Adjusted R } \\
\text { Square }\end{array}$ & $\begin{array}{c}\text { Std. Error of the } \\
\text { Estimate }\end{array}$ & Durbin-Watson \\
\hline 1 & $.883^{\mathrm{a}}$ & .780 & .717 & 4.45295 & .723 \\
\hline
\end{tabular}
a. Predictors: (Constant), prptran_kas, prptran_piutng
b. Dependent Variable: likuiditas

Dari tabel 9, dapat diketahui nilai $\mathrm{R}^{2}$ (Adjusted R Square) adalah 0,780 Jadi sumbangan pengaruh dari variabel independen (Perputaran Piutang dan Perputaran Kas) yaitu $78,0 \%$ sedangkan sisanya sebesar $22,0 \%$ dipengaruhi oleh faktor lain yang tidak diteliti.

\section{SIMPULAN}

Berdasarkan hasil dan analisis pengujian dapat ditarik kesimpulan sebagai berikut :

1. Perputaran Piutang pada PT.Ultrajaya Milk Industry \& Trading Company Tbk, selama kurun waktu 10 tahun dari tahun 2005-2014 cenderung kurang baik, dikarenakan perputaran piutang mengalami peningkatan, sehingga dana perusahaan mengendap di distributor. penigkatan perputaran piutang tersebut cukup tinggi setiap tahunnya, dan yang paling tinggi kenaikan tingkat perputaran piutang adalah pada tahun 2013 yaitu sebesar 10,4 kali. Naiknya tingkat perputaran piutang dikarenakan tingkat pengumpulan rata-rata piutang meningkat dibandingkan dengan rata-rata piutang tahun sebelumnya.

2. Perputaran Kas pada PT. Ultrajaya Milk Industry \& Trading Company Tbk, selama kurun waktu 10 tahun. Dari tahun 2005-2014 tidak baik dilihat dari perputaran kas tahun 2005-2008 mengalami kenaikan dari 6,8 kali ke 13,4 kali. Dan tahun 2009-2010 membaik dilihat dari perputaran kas yang mengalami penurunan dari 8,5 kali ke 6,3 kali. Namun ditahun 2011-2014 tidak mengalami peningkatan atau penurunan yang terlalu banyak.

3. Likuiditas diukur dengan Current ratio pada PT Ultrajaya Milk Industry \& Trading Company Tbk. Dari tahun 2005-2014 mengalami tingkat yang berbedabeda. Current ratio merupakan rasio yang menunjukkan hasil return atas jumlah 
aktiva yang digunakan oleh perusahaan. Current ratio tertinggi terjadi pada tahun 2014. Disebabkan beberapa hal diantaranya besarnya kas bersih yang digunakan untuk aktivitas investasi Rp.151.300.000.000,00 dan kas bersih yang digunakan untuk aktivitas pendanaan sebesar Rp.99.000.000.000,00 Sedangkan current ratio paling rendah pada tahun 2006. Dikarenakan kas bersih yang diperoleh dari aktivitas investasi sebesar Rp.63.695.592.183,00 dan kas yang digunakan untuk aktivitas pendanaan sebesar Rp.14.751.898.141,00 jauh lebih rendah dibandingkan dengan tahun 2014.

4. Dari hasil dalam penelitian ini dapat diketahui bahwa variabel independent perputaran piutang mempunyai pengaruh signifikan terhadap likuiditas pada PT Ultrajaya Milk Industry \& Trading Company Tbk. Perputaran piutang yang tinggi dapat menigkatkan likuiditas karena jumlah piutang tak tertagih semakin sedikit. Namun perputaran piutang yang terlalu tinggi juga dapat menurunkan likuiditas.

5. Berdasarkan hasil analisis data yang telah dilakukan, menunjukkan bahwa variabel independent perputaran kas tidak memiliki pengaruh yang signifikan terhadap likuiditas pada PT. Ultrajaya Milk Industry \& Trading Company Tbk. hasil penelitian ini menunjukkan bahwa pihak manajemen keuangan perusahaan kurang efektif dalam mengelola kas yang dimiliki, sehingga perputaran kas yang terjadi dari tahun ke tahun rata-rata cenderung menunjukkan angka perputaran yang fluktuatif (naik turun). Perputaran kas yang terlalu tingi dapat mengakibatkan perusahaan kekurangan dana sehingga dapat menurunkan likuiditas perusahaan.

6. Hasil penelitian ini menunjukan bahwa terdapat $78,0 \%$ sumbangan pengaruh dari varibel independen (pengaruh perputaran piutang dan perputaran kas) terhadap tingkat likuiditas sedangkan sisanya 22,0\% dipengaruhi oleh faktor lain yang tidak diteliti dalam penelitian ini. Secara parsial perputaran piutang berpengaruh signifikan terhadap likuiditas dengan melihat nilai signifikansi $0,026 \leq 0,05$. Secara simultan variabel perputaran piutang dan perputaran kas berpengaruh terhadap likuiditas hal tersebut dapat dilihat dari nilai f hitung $\geq \mathrm{f}$ tabel $(12,, 404 \geq 9,27)$. 


\section{DAFTAR PUSTAKA}

Astuti, Dewi. (2008). “Manajemen Keuangan Perusahaan”, Ghalia Indonesia : Jakarta.

Brigham dan Houston. (2010). “Dasar-Dasar Manajemen”, Edisi Ke 11, Buku Pertama, Salemba Empat : Jakarta.

Fahmi, Irham. (2012). “ Pengantar Manajemen Keuangan”, Cetakan Pertama, Alfa Beta CV, Bandung.

Fee, Reeve, Warren. (2005). "Pengantar Akuntansi”, Edisi 21, Penerbit Salemba Empat : Jakarta.

Ghozali, Imam. (2005). “Aplikasi Analisis Multivariate dengan program SPSS”, Badan Penerbit Universitas Diponegoro : Semarang.

Hanafi M Mamduh dan Halim Abdul. (2012). “Analisis Laporan keuangan”, Edisi Keempat, Cetakan Kedua, Sekolah Tinggi Ilmu Manajemen (YKPN) : Yogyakarta.

Hanafi M Mamduh dan Halim Abdul. (2010). “Analisis Laporan Keuangan”, Edisi Keempat, Cetakan Pertama, Sekolah Tinggi Ilmu Manajemen (YKPN) : Yogyakarta.

Handoko, Hani. (2011). “Manajemen”, Edisi Kedua, Cetakan Ke 21, BPFE : Yogyakarta.

Harjito D Agus dan Martono. (2012). “Manajemen Keuangan”, Edisi Kedua, Penerbit Ekonisia Sleman : Yogyakarta.

Husnan Suad dan Pudjiastuti Enny. (2005). “Manajemen Keuangan”, Edisi Kedua, Cetakan Keenam, Penerbit Universitas Terbuka : Jakarta.

Kasmir. (2014). “Analisis Laporan Keuangan”, Penerbit Rajawali Pers : Jakarta.

Kasmir. (2010). "Pengantar Manajemen Keuangan", Cetakan Kedua, Kencana Prenada Media Group : Jakarta.

Kuncoro, Mudrajad. (2009). "Metode Riset Untuk Bisnis dan Ekonomi", Edisi 3, Erlangga : Yogyakarta. 
Lukman, Syamsudin. (2007). “Manajemen Keuangan Perusahaan”, PT. Raja

Grafindo Persada : Jakarta.

Margaretha, farah. (2005). "Teori dan Aplikasi Manajemen Keuangan", Penerbit Grasindo : Jakarta.

Prawironegoro Darsono dan purwanti ari. (2010). "Penganggaran Perusahaan", Edisi Kedua, Penerbit Mitra Wacana Media : jakarta.

Riyanto, Bambang. (2008). "Dasar-Dasar Pembelanjaan Perusahaan”, Cetakan Kedelapan, Edisi Keempat, Penerbit BPFE : Yogyakarta.

Riyanto, Bambang. (2009). "Dasar-Dasar Pembelanjaan Perusahaan", Cetakan Kesembilan, Edisi Keempat, Penerbit BPFE : Yogyakarta.

Riyanto, Bambang. (2011). "Dasar-Dasar Pembelanjaan Perusahaan”,

Cetakan Kesebelas, Edisi Keempat, Penerbit BPFE : Yogyakarta.

Santoso, Singgih. (2008). "Statistik Parametik", PT. Alex Media Komputindo : Jakarta.

Santoso. (2010). Singgih, "Statistik Parametik", PT. Alex Media Komputindo : Jakarta.

Sartono, Agus. (2008). “Manajemen Keuangan Teori dan Aplikasi”, (4th ed), Yogyakarta: BPFE.

Subramanyan. (2010). “Analisis Laporan Keuangan”, Edisi Ke 10, Salemba Empat : Jakarta.

Sugiyono. (2011). "Metode Penelitian Kualitatif, Kuantitatif dan Kombinasi", Alfabeta : Bandung.

Sutrisno. (2013). "Manajemen Keuangan", Ekonisia, Kampus Ekonomi UI : Yogyakarta.

Syafri, Sofyan Harahap. (2013). "Analisis Kritis atas Laporan Keuangan”,

Cetakan Kesebelas, Penerbit PT. Raja Grafindo Persada : Jakarta.

Wijayanto, Dian. (2012). “Pengantar Manjemen”, PT. Gramedia Pustaka Utama: Jakarta. 